\title{
LENGTH-WEIGHT RELATIONS OF 22 FISH SPECIES FROM THE LITTORAL ZONE OF THE EASTERN IONIAN SEA, GREECE
}

\author{
Varvara LIOUSIA ${ }^{1}$, Stratos BATZIAKAS ${ }^{1}$, Nikos PANAGIOTOU ${ }^{1}$, Irini DAOUTI ${ }^{1}$, \\ Emmanouil KOUTRAKIS ${ }^{2}$, and Ioannis D. LEONARDOS ${ }^{1 *}$ \\ ${ }^{1}$ Laboratory of Zoology, Department of Biological Applications and Technology, University of Ioannina, Greece \\ ${ }^{2}$ Fisheries Research Institute, National Agricultural Research Foundation, Nea Peramos, Kavala, Greece
}

Liousia V., Batziakas S., Panagiotou N., Daouti I., Koutrakis E., Leonardos I.D. 2012. Length-weight relations of 22 fish species from the littoral zone of the Eastern Ionian Sea, Greece. Acta Ichthyol. Piscat. 42 (1): 69-72.

\begin{abstract}
Length-weight relations are presented for 22 fish species caught in the littoral zone of the eastern Ionian Sea. Mean values of $b$ ranged from 2.58 to 3.43. For Greek waters no information regarding the LWR existed for 2 of the recorded species. This is the first study on the LWR for species of the littoral zone of the eastern Ionian Sea which may be helpful in future fisheries studies in this area.
\end{abstract}

Keywords: Length-weight relation, littoral zone, eastern Ionian Sea

Length-weight relations (LWR) are of great importance for fisheries research as they allow the conversion of growth-in-length equations to growth-in-weight equations to be used in stock assessment models, the estimation of biomass from length observations, the estimation of the condition of the fish, and can be used to compare the life histories of certain species between regions and other aspects of fish population dynamics (Gonçalves et al. 1997, Moutopoulos and Stergiou 2002, Froese and Pauly 2011).

In Greek marine ecosystems length-weight relations for commercial fish species are available mostly for the Aegean Sea (Stergiou and Politou 1995, Petrakis and Stergiou 1995, Stergiou and Moutopoulos 2001, Moutopoulos and Stergiou 2002, Koutrakis and Tsikliras 2003, Karakulak et al. 2006). The length-weight relations of the fish species of the Ionian Sea are poorly known, however (Stergiou and Moutopoulos 2001, Froese and Pauly 2011) and such information for the littoral zone is absent altogether.

The aim of the presently reported study was to establish the length-weight relation of 22 fish species, either adult or juvenile, caught in the littoral zone of the eastern Ionian Sea. The results reported may be helpful in the fisheries management and will constitute a benchmark for future research in this area.

Samples were collected in two different estuarine habitats in the eastern Ionian Sea (Station I: Port of Igoumenitsa $39^{\circ} 31^{\prime} 04.63^{\prime \prime} \mathrm{N}, 20^{\circ} 13^{\prime} 29.38^{\prime \prime} \mathrm{E}$, Station II Amvrakikos Gulf $\left.39^{\circ} 00^{\prime} 10.92^{\prime \prime} \mathrm{N}, 20^{\circ} 45^{\prime} 22.35^{\prime \prime} \mathrm{E}\right)$. Station I is exposed to wind and waves. It is a part of the Kalamas River estuarine ecosystem and its sea-grass habitat comprises predominantly of Zostera sp. providing a landscape of patchy sea grass amongst areas of bare sand. The Amvrakikos Gulf is a shallow semi-enclosed embayment in the Ionian Sea. The sea-grass habitat of the station comprises predominantly of dense Posidonia oceanica vegetation.

Fish species were collected at each station on a monthly basis from July of 2008 through March of 2010 using a beach seine $(16-\mathrm{m}$ long and $1.4-\mathrm{m}$ high, mesh size of 2-4 mm) and were preserved in $4 \%$ neutralized formalin. In the laboratory, each specimen was identified to the species level and the standard length and weight were measured to the nearest $\mathrm{cm}$ and $\mathrm{g}$, respectively.

The relations between the length $(L)$ and weight $(W)$ of a fish were expressed by the equation $W=a L^{b}$, where $W$ is the total weight, $L$ is the total length, $a$ is a coefficient related to body form and $b$ is an exponent indicating isometric growth when equal to 3 and allometric growth when different to 3 (positive if $b>3$, negative if $b<3$ ) (Beverton and Holt 1957, Froese 2006). The parameters $a$ and $b$ of the length-weight relations were estimated by the least-square method based on the predictive or Type I linear regression model (Sokal and Rohlf 1981), using $W$ as the dependent variable and $L$ as the independent variable, $\log (W)=\log (a)+b \log (L)$. The $b$-value for each species was tested by Student's $t$-test to verify that it was significantly different from the predictions for isometric growth $(b=3)$. Analysis of covariance (ANCOVA) was used to compare the regression lines between stations (Zar 1996)

\footnotetext{
* Correspondence: Dr. Ioannis D. Leonardos, Laboratory of Zoology, Department of Biological Applications and Technology, University of Ioannina,
} GR-45110 Ioannina, Greece, phone: +302651007313, fax: +302651007987, e-mail: ileonard@cc.uoi.gr. 
高

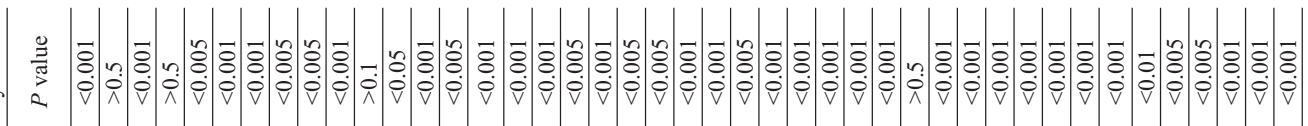

-

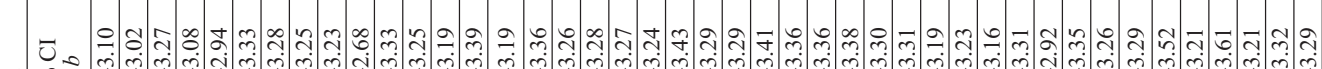
年

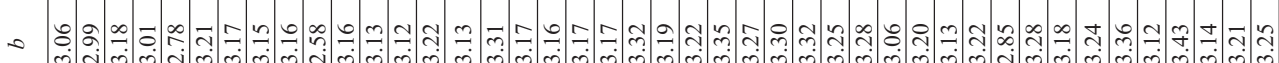

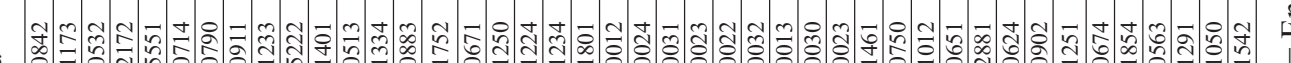

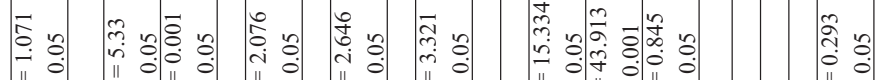

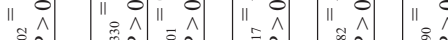

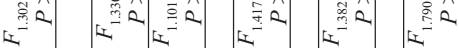

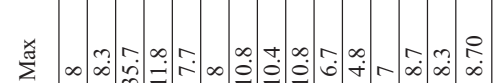

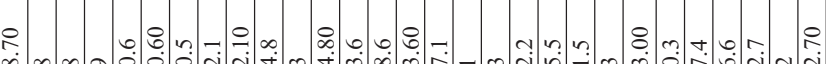

$\geq \sum$

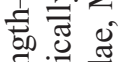

递:

$\Xi$ 要焉

प्山े

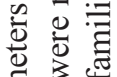

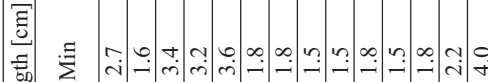

可

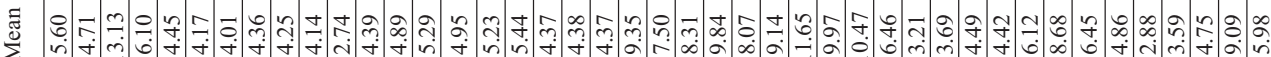

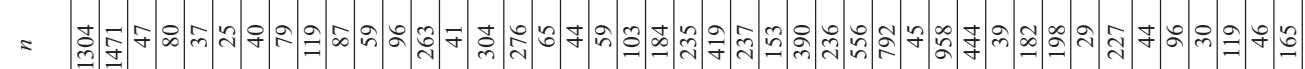

ठี

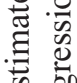


and when no different, stations were combined. The coefficient of determination $r^{2}$ was calculated.

A total of 7905 specimens collected and studied represented 12 families and 22 species. The sample size ranged from 25 individuals for Parablennius sanguinolentus (Pallas, 1814) to 1471 for Atherina boyeri Risso, 1810. All of the regressions were highly significant $(P<0.005)$ and the values of $r^{2}$ ranged from 0.95 for Syngnathus abaster Risso, 1827 and Atherina boyeri (Station I) to 0.99 for Mullus surmuletus L. The high values of correlation coefficient $r^{2}$ indicate a high degree of positive correlation between standard length and total weight of all 22 fish species. For 8 species the regression lines were not statistically different between stations and LWRs were combined and referred to as eastern Ionian Sea (Table 1).

The mean values of $b$ ranged from 2.58 for Sardina pilchardus (Walbaum, 1792) (Station I) to 3.43 for Diplodus vulgaris (Geoffroy Saint-Hilaire, 1817). For the majority of the species the slopes of $b$ were significantly $(P<0.05)$ higher than 3.0 , exhibiting a positive allometric growth. The estimated values of $b$ were close to $3.0(P$ $>0.05)$ showing isometric growth for three species while only for one species the mean values of $b$ showed a significant difference $(P<0.05)$ lower than 3.0 reflecting a negative allometric growth (Table 1). At this point, it has to be stated that the species of the families of Mulidae, Mugilidae, and Sparidae are represented by juvenile specimens. Also the species of the remaining families were represented by small- and medium sized specimens compared to the published maximum lengths recorded for the species and available mean lengths at maturity. Hence the use of the length-weight relation parameters should be limited to the observed length ranges (Petrakis and Stergiou 1995, Gonçalves et al. 1997). Extrapolation of these parameters to different length ranges (higher or lower) should be avoided (Bagenal and Tesch 1978).

As shown in Table 1 there is a significant statistical between stations difference in the LWRs for five species: Atherina boyeri; Liza aurata (Risso, 1810); Liza saliens (Risso, 1810); Parablennius sanguinolentus; and Symphodus cinereus (Bonnaterre, 1788). Even though the change of $b$ values depends primarily on the shape and wellbeing of the species, various factors may be responsible for that difference. According to Bagenal and Tesch (1978), Gonçalves et al. (1997), Taskavak and Bilecenoglu (2001), and Özaydin and Taskavak (2006), the parameter $b$, unlike the parameter $a$, may vary seasonally, daily, and between habitats. Also gonad maturity, sex, diet, stomach fullness, health, and preservation techniques, as well as season could attribute to that difference. However none of these factors were taken into consideration in the presently reported study (Tesch 1971, Wootton 1998).

For Greek waters no information regarding the length-weight relations existed for 2 of the recorded adult species (Syngnathus typhle L. and Gobius niger L.), while apart from Mullus surmuletus no length-weight relations information were available in FishBase for the littoral zone of the eastern Ionian Sea (Froese and Pauly 2011).

\section{ACKNOWLEDGEMENTS}

The research Project is co-funded by the European Union- European Social Fund (ESF) and National Sources, in the framework of the program "HRAKLEITOS II" of the "Operational Program Education and Life Long Learning" of the Hellenic Ministry of Education, Life Long Learning and religious affairs.

\section{REFERENCES}

Bagenal T.B., Tesch F.W. 1978. Age and growth. Pp. 101-136. In: Bagenal T. (eds.). Methods for assessment of fish production in fresh waters. IBP handbook 3. Blackwell Science Publications, Oxford.

Beverton R.J.H., Holt S.J. 1957. On the dynamics of exploited fish populations. Fish and Fisheries Series 11. Chapman and Hall, London.

Froese R. 2006. Cube law, condition factor and weight-length relationships: history, meta-analysis and recommendations. Journal of Applied Ichthyology 22 (4): 241-253. DOI: $10.1111 / j .1439-0426.2006 .00805 . x$

Froese R., Pauly D. (eds.). 2011. FishBase. [version 12/2011] http://www.fishbase.org.

Gonçalves J.M.S., Bentes L., Lino P.G., Ribeiro J., Canário A.V.M., Erzini K. 1997. Weight-length relationships for selected fish species of the small-scale demersal fisheries of the south and south-west coast of Portugal. Fisheries Research 30 (3): 253-256.

DOI: $10.1016 / \mathrm{S} 0165-7836(96) 00569-3$

Karakulak F.S., Erk H., Bilgin B. 2006. Length-weight relationships for 47 coastal fish species from the northern Aegean Sea, Turkey. Journal of Applied Ichthyology 22 (4): 274-278. DOI: $10.1111 /$ j.1439-0426.2006.00736.x

Koutrakis E.T., Tsikliras A.C. 2003. Length-weight relationships of fishes from three northern Aegean estuarine systems (Greece). Journal of Applied Ichthyology 19 (4): 258-260. DOI: 10.1046/j.1439-0426.2003.00456.x

Moutopoulos D.K., Stergiou K.I. 2002. Length-weight and length-length relationships of fish species from the Aegean Sea (Greece). Journal of Applied Ichthyology 18 (3): 200-203. DOI: 10.1046/j.1439-0426.2002.00281.x

Özaydin O., Taskavak E. 2006. Length-weight relationships for 47 fish species from Izmir Bay (eastern Agean Sea, Turkey). Acta Adriatica 47 (2): 211-216.

Petrakis G., Stergiou K.I. 1995. Weight-length relationships for 33 fish species in Greek waters. Fisheries Research 21 (3-4): 465-469.

DOI: 10.1016/0165-7836(94)00294-7

Romer G.S. 1990. Surf zone fish community and species response to a wave energy gradient. Journal of Fish Biology 36 (3): 279-287.

DOI: $10.1111 / j .1095-8649.1990 . t b 05609 . x$

Sokal R.R., Rohlf F.J. 1981. Biometry. 2nd ed. Freeman, San Francisco.

Stergiou K.I., Moutopoulos D.K. 2001. A review of length-weight relationships of fishes from Greek marine waters. Naga, the ICLARM Quarterly 24 (1-2): 23-39.

Stergiou K.I., Politou C.Y. 1995. Biological parameters, body length-weight and length-height relationships for various 
species in Greek waters. Naga, the ICLARM Quarterly 18 (2): $42-45$.

Taskavak E., Bilecenoglu M. 2001. Length-weight relationships for 18 Lessepsian (Red Sea) immigrant fish species from the eastern Mediterranean coasts of Turkey. Journal of the Marine Biological Association of the United Kingdom 81 (5): 895-896.

DOI: $10.1017 / \mathrm{S} 0025315401004805$

Tesch F.W. 1971. Age and growth. Pp. 98-130. In: Ricker W.E. (ed.). Methods for assessment of fish production in fresh waters. Blackwell Scientific Publications, Oxford.
Wootton R.J. 1998. Ecology of teleost fishes. 2nd edn. Chapman and Hall, London.

Zar J.H. 1996. Biostatistical analysis, 3rd. edn. Prentice Hall, New Jersey.

Received: 6 September 2011

Accepted: 24 January 2012

Published electronically: 31 March 2012 